\title{
Thinking Skill Education and Transformational Progress in Malaysia
}

\author{
Nooraini Othman ${ }^{1} \&$ Khairul Azmi Mohamad ${ }^{2}$ \\ ${ }^{1}$ UTM Perdana School, Universiti Teknologi Malaysia Kuala Lumpur, Malaysia \\ ${ }^{2}$ Yayasan Ilmuwan, Kuala Lumpur, Malaysia \\ Correspondence: Nooraini Othman, UTM Perdana School, Universiti Teknologi Malaysia Kuala Lumpur, Jalan \\ Semarak, 54100 Kuala Lumpur, Malaysia. Tel: 603-2615-4371. E-mail: p-noraini@utm.my; \\ khairunnur69@yahoo.com
}

Received: November 12, 2013 Accepted: January 22, 2014 Online Published: March 23, 2014

doi:10.5539/ies.v7n4p27 URL: http://dx.doi.org/10.5539/ies.v7n4p27

\begin{abstract}
This paper intends to highlight the issues in thinking skills development and efforts made in addressing these issues in Malaysia. The education system in Malaysia has undergone a huge transformational progress particularly in the field related to the development of thinking skill. Traditionally, thinking skill was not specifically cultivated in the education syllabus. What moved as a global agenda in the realm of education, thinking skill was embraced as an important subject matter that needs a specific attention. It was later embedded in the teachers' training activities and translated into many forms, curricular and extra-curricular activities alike. Students are trained right from school up to tertiary levels. The move is ongoing and continuosly progressing.
\end{abstract}

Keywords: thinking skill education, education in Malaysia, teachers' training, school-based assessment

\section{Introduction}

Education sector is one of the sectors which contribute to the development of human capital. Regarded as development agent, this sector also bridges knowledge, training, potential, interest and other human quality elements as human capital to a more dynamic, innovative and progressive dimensions in order to achieve the country's aspiration in becoming a developed and high income nation. Thus, the role of education is to shape the quality of the students not only from the aspects of academic, co-curriculum and personality but also a paradigm shift in enhancing human capital quality through innovation and intellectual capability. This matter is seen to be compatible with the country's education system especially those involved in producing human capital with high thinking skill, good personality, creativity, innovativeness and competitiveness. The Malaysian government's seriousness in developing human capital can be seen in terms of the allocation of education budget of $20-25 \%$ of the overall budget (Noor, 2008) and a sum of RM29.3 billion was allocated for education in 2011.

Malaysia as a developing country is targeting to become a fully developed nation by the year 2020. Better known as Vision 2020, the Malaysian former prime minister, Dr. Mahathir Mohamad who inspired Vision 2020 had stressed that Malaysia should not be developed only in the economic sense. It must also be a nation that is fully developed along all the dimensions such as economically, politically, socially, spiritually, psychologically and culturally.

The government has specifically term the plan or program as "Innovative Human Capital" as to relate the link between educational (the process) and creative, innovative and collaborative entrepreneurial human capital (the outcome). According to the National Innovation Council (NIC) which introduced the National Innovation Model in 2007 (NIM), the plan is "to transform Malaysia from a resource-based to an innovation-based economy". Thus, it is also high time to review the implementation that are taking place at the school level (especially the secondary school) to discover whether the teaching of thinking skills is effectively carried out.

One of the aims of schooling is to develop the students' thinking skills. The major issue of today's education is that "many studies have begun to reveal symptoms of decline in students' ability to think well, especially when schools begun to focus on the mastery of subject content rather than the processes of deriving the products" (Rosnani \& Suhailah, 2003). Therefore, the correct and innovative ways of teaching thinking skills must be found. Given these circumstances, the aim of this paper is to highlight the relevant issues in developing thinking skills among the students and the efforts made in addressing these issues specifically in Malaysia. 


\section{Ways of Teaching Thinking Skills}

According to Jones and Haynes (1999), "the teaching of thinking skills may be included in the curriculum in a variety of ways. They may be taught as skills within their own right under the label of critical thinking. They may be taught as a reflective exercise on how thinking occurs within and across the subject disciplines (the infusion approach). They may be taught within a program of philosophy for children. Or they may be taught as a particular way of encountering and comprehending the subject disciplines (the framework approach)".

Swartz and Perkins (1989) exemplified the description of various infused thinking skills lesson as "reliability, causal explanation and the use of evidence for inference. Standard subject content is restructured in the infusion approach so that these approaches are highlighted. As a result students become conscious of them and thus gain a 'metacognitive awareness' which extends to cover a range of different thinking skills, depending upon the teacher's choice".

Based on the above statement, the teaching of thinking skills may best be implemented via the combination of infusion approach whereby the process has been incorporated into the classroom subject and also stand-alone approach. Halpern (1999) commented that "Many authorities in higher education did not enthusiastically embrace the idea that college students should receive explicit instruction in how to think".

Explicit instruction or teaching involves directing student's attention toward specific learning in a highly structured environment which focused on producing specific learning outcomes. Topics and contents are broken down into small parts and taught individually. It involves explanation, demonstration and practice. Students are provided with guidance and structured frameworks. Topics are taught in a logical order and directed by the teacher.

However, explicit instruction or teaching has its own challenges. Hashim (2004) stated that "the biggest problem with the teaching of critical and creative thinking is teachers' lack of understanding and knowledge and the accompanying skills on thinking. No proper education and training on thinking have been offered to all teachers, especially in-service teachers whereas the Ministry and subject teachers prefer to adopt the infusion approach in teaching thinking".

How do we expect the students to learn thinking skills when the teachers are not equipped with the necessary skills and knowledge? Although we cannot generalize the situation, it is worth considering whether Malaysian teachers who are supposed to teach creative and critical thinking skills do possessed the required skills. If they don't possess the necessary skills, what are the corrective actions that can be implemented and how to implement the necessary actions.

Ghafar et al. (2010) has revealed that "after 22 years of the Integrated Curriculum for Secondary Schools implementation, the teachers are still poor in the teaching and learning methods as needed by the integrated curriculum practice". However, in their research, they stated that much more experienced teachers are capable of delivering their teaching as required by the curriculum's standard. Their research has also identified that most teachers prefer the using of "speech and chalk" method and were unable to adjust to students" variety of learning styles.

Sharifah (2000) stated that "teachers need to be constantly aware of teaching styles". In fact, teachers should not restrict themselves to the same teaching preference due to the fact that students have different levels and ways of learning, meaning that some students are fast learner and some are moderate or even slow learners.

Baumfield and Oberski (1998) stated that "very little is known about the motivation of teachers who become involved in thinking skills programs, analysis of their perceptions will contribute to our understanding of why a particular program is chosen and the extent to which the needs of the teachers are consistent with its aims".

\section{Issues in Teaching Thinking Skill in Malaysia}

In Malaysia, despite lots of researches conducted on thinking skills either on students or teachers, the remark made by the Crown Prince of Perak, Malaysia, Shah (2004) will make us to reconsider about the education system in Malaysia. His Royal Highness said, "Do we want our students to be examination oriented driven but with lack of thinking skills ability?"

When we talk about teacher's thinking skills, either creative thinking or critical thinking, the teachers involved in teaching the subjects matter should possess high level of the skills. However, Aznizah (2004) found that the creativity of the science and mathematics teacher under study is at moderate level but still better than the non science and mathematics teachers. Moderate level here should not be tolerated due to the fact that in order to stimulate the students' interest in science and mathematics subjects, the teachers play a significant role. 
Choy and Cheah (2009) noted that teachers did not seem to understand the requirement needed to cultivate critical thinking among students. Although teachers perceive that they are encouraging critical thinking in the classroom, they are merely focusing on the comprehension of the subject matter.

Based on Aznizah (2004), Mahyudin et al. (2004), Rosnani (2004) and Choy and Cheah (2009), it is clear that the building of thinking skills among Malaysian students can be jeopardized due to the fact that the teachers are not highly skilled in transforming the skills from the classroom teaching (process) to the students (application).

Can students improve their thinking skills on their own or do they have to be taught the proper techniques and correct approaches so that their thinking skills will be above average? Sternberg and Williams (2002) noted that thinking is a natural process and therefore students may not need to be taught formally. However, But Duron, Limbach, and Waugh (2006) argued that although thinking is a natural process, formal teaching is still needed if excellence is the objective to be achieved. Black (2005) found that if students were taught how to think, they can improve their thinking skills.

According to Mahyudin et al. (2004), "In Malaysia, where rapid changes are taking place particularly in the technical and industrial sectors, it is imperative that thinking skills should be made the educational goals where students can be trained to make sense of new information and not just acquisition of knowledge. The responsibility therefore lies in education where it is important that students be trained to think critically and creatively". However, "it is realized that many teachers are not fully capable of incorporating thinking skills in their teaching strategies".

Thus, we can take note here that the competency of the teachers in teaching thinking skills in classroom is also one of the crucial factors that helps to foster the development of thinking skills among the students. What is the predetermined standard of the teachers and what kind of training the teachers should be attending?

Hashim (2004) highlighted two important issues, which are as follows: First issue is that "the basic issue that justifies the call for teaching thinking in schools is the evidence that after 11 years of schooling, many students are unable to apply the content knowledge acquired in school to real world problems. The business sector is complaining about the quality of the graduates they received from the universities who sometimes could not even comprehend instruction manuals, what more the way a piece of equipment works".

The business sectors as we know it will always seek for dynamic executives who are able to "work with a minimum supervision". The situation here is whether the newly employed graduates are being exposed to training or courses when they joined the company. There are normally two types of training, i.e. induction course which is carried out to introduce the company's nature of business, vision and mission and another type of training is focusing on job related.

Second issue is that "this meticulous research was mostly kept on the library shelves gathering more dust and was never ever to inform the practitioners in the Ministry and schools. Therefore, practitioners were unable to use research as framework for making practical decisions." The reasons are "In the context of Malaysia, most of them could not get access to the relevant literature, do not possess the learning culture for self improvement, are too busy teaching and preparing students for examinations or are complacent with their practices despite the declining educational standards".

According to Noor (2008), "There is a lack of higher order thinking ability among students and there is a need to prepare students for future effective problem solver, thoughtful decision maker and life-long learning. There is a necessity for students to be independent thinkers as an increasingly wide range of jobs in future requires capable worker / employees who have the ability to think". He also stressed that "teaching higher order cognition helps students to become independent learners".

\section{Transformation in Malaysia}

Despite the shortfall of the level of thinking skills by some students and also the inexperienced teachers who have to teach thinking skills to the students as highlighted by researches conducted in Malaysia, the government has constantly revised and amended the policy and systems. For the purpose of this research, the authors will highlight some of the education reforms by the government.

\subsection{Malaysia Smart School}

The Malaysian Smart School concept which was introduced in 1997 is set to bring a whole new paradigm into the national education system. Malaysian Smart School (MSS) was one of the seven flagship applications that are part of Malaysia's Multimedia Super Corridor Project.

The MSS concept was to lead changes in "Malaysia's culture and practices in both primary and secondary 
schools moving away from memory based learning designed for the average student to an education that stimulates thinking, creativity and caring in all students, caters to individual abilities and learning styles".

Two of its five strategies focus on thinking, firstly is, "emphasise intellectual, emotional, spiritual, and physical growth, concentrating on thinking, developing and applying values, and using correct language across the curriculum" and secondly is to "produce a technologically literate work force that can think critically, encouraging thought and creativity across the curriculum and applying technology effectively in teaching and learning".

The MSS's new curriculum is based on an integrated four elements as follows:

i. Knowledge - such as content knowledge and problem solving knowledge.

ii. Skills - such as critical and creative thinking skills and knowledge acquisition skills.

iii. Values - such as respects, honesty and justice.

iv. Language - correct usage of reading, writing and oral communication across the curriculum.

$\mathrm{Ng}$ et al. (2009) in the research concluded that the MSS project "signifies a dramatic change in the local educational system whereby information technology is utilized in every aspect of education and students are required to take much greater responsibilities of their own learning". The research found that the MSS project has brought the level of education to a higher level in such a way that it gave the students greater responsibilities on their own learning, that is, the students have the opportunity to set their own pace of learning.

Ong (2006) stated that the MSS project has "the strong advocacy of explicit teaching of thinking skills, with different sets of skill vocabularies stipulated for two types of thinking - critical thinking and creative thinking". The government has actually put lots of effort in improving and developing the standard of education system in order to keep it relevant or contemporary with the technological changes.

\subsection{Innovative Human Capital Development Plan}

Another reform introduced by the government was the Implementation Plan for Development of Innovative Human Capital at Tertiary Level ("the IHCD Plan") by the Ministry of Higher Education (MoHE) in 2010. The government realized that for Malaysia to successfully achieve the Vision 2020, the main focus should be given to developing the human capital. This IHCD plan is however being introduced at tertiary level, meaning to say that the priority is given to the students that have already completed their secondary schools and continue their study at the university level.

The aim of IHCD plan is to foster Malaysia towards an innovative society which is one of the factors that will lead Malaysia to become a fully developed country by year 2020. The IHCD plan is based on four elements namely the education, government, industry and ventures. One of the recommendations made by the MoHE is to "review, revamp and restructure the curriculum at tertiary institutions namely TEST (Technical Education and Skills Training) and IHL (Institutions of Higher Learning) both in rural and urban areas to incorporate elements that inculcate creativity and innovation alongside collaboration and entrepreneurial skills".

The Agenda on Innovative Malaysia (AIM, 2009) report stated that one of the reasons why Malaysia is far from achieving the innovative society status is that "the curriculum lacks elements of creativity and innovation". This directly has a close bearing on the education system.

As mentioned above that the four elements or better known as the pillars that stand as the platform for the IHCD plan, (which consists of education, government, industry and ventures) education has been identified as the core factor that is critical in ensuring that the IHCD plan meets it objective.

According to the National Innovative Model (NIM, 2007), the concept of 'Innovative Malaysia' requires the "creation and development of a society that embraces a culture of creativity and innovation". In general, the IHCD plan has made it clear that the function and responsibilities of each of the four elements to be as follows, "Education should be able to create a workforce steeped in an innovation-culture; Government must be responsible for putting into place appropriate policies and the legal framework; Industry takes care of high-end design, prototyping and manufacturing while Ventures deal with entrepreneurial and financial activities that fuel an innovation-led economy".

Ismail and Ghani (2011) stated that "education is one of the main medium in the effort of developing human capital that has a strong identity, amiable personalities, prominent knowledgeable and highly skilled in meeting the needs of Malaysia to be a developed country by 2020". They have also stressed that "desired human capital should also be capable of engaging in critical and creative thinking, competent in problem solving, capable in 
creating new opportunities and possesses perseverance as well as capable in facing the ever changing global environment".

Sahandri \& Kumar (2010) stated that generics skills are needed to produce human capital with a first class mentality. Although there is no standard definitions of what is "generic skills" because of the terms being used varies across countries, it is commonly accepted universally that thinking skills is one of the elements that are theoretically accepted universally.

Recently, the government planned to introduce a special education programme "i-Think" which is designed to encourage innovative thinking skills among children at 1,000 schools by the year 2013 and all schools by 2014 (NST, 2012). It is reported that the Malaysian Prime Minister, Najib Razak said the programme was initially implemented as pilot projects at 10 schools and it had shown success in instilling creative thinking among the youth. The programme was part of the national education transformation plan to create a thinking and creative younger generation in view that they will be innovative, analytical, able to adapt to crisis, throw ideas, think out-of-the-box and able to solve problems. In accordance with this plan, the skills will be incorporated in the modules at the teacher training institutes to prepare new teachers to handle the programme.

\subsection{School Based Assessment System}

Previously, Malaysia's schools are based on centralized examination. Ministry of Education has proposed to change the current centralized examination system towards School Based Assessment system ("SBA"). The SBA system has just been implemented since early 2012. The SBA system is actually a combination of centralized examination and school based assessment. However, under SBA system, the centralized examination may take on a different form. Teachers under SBA system are expected to have greater opportunities to understand their students because they are empowered to come up with customized (personalized) classroom instructions and teaching method and techniques. The teachers are expected to be very observable on their students or during classroom activities. Recently, based on inputs and comments from the public, the SBA system has been revised and improved by the ministry.

\section{Conclusion}

The transformation of the Malaysian education system particularly in the area of thinking skill development is an ongoing process. It is yet to achieve its mature level. Studies proved that the process must start with equipping the teachers with the right knowledge and skills. If the agenda is good but the implementation is weak, it is not going to achieve the intended objectives. Thus, the teachers must first be trained to the highest level of mastery in order to produce the required thinking quality students.

Teachers themselves must understand and aware of their own task that is to be initiative enough to independently upgrade their own skills and capabilities as far as teaching thinking is concerned. It is not enough for teachers to promote creativity and innovation to their students. Creativity and innovation must be reflected in the teachers themselves such as in their teaching methods and their approach to delivering knowledge.

It is also not the job of a single teacher to be designated as a thinking skill teacher. Every teacher must play their role through their subject matters taught. Every subject must purposely incorporate the "thinking elements" in the students. Ultimately, once they are embedded in the syllabus and curriculum as well as being practiced all year round, they will become cultural in nature. It will ultimately create a "thinking culture". By this, the aim of creating a systematic and scientific 'thinking society' is achievable.

The experience on managing the issues in Malaysia as described by this paper could also be learnt by other developing countries. However, the approach as practiced in Malaysia may have to be modified to suit a particular country specific needs and culture.

\section{References}

Aznizah, N. K. (2004). Kajian Tentang Kreativiti Guru Sains dan Matematik Sekolah Menengah. Tesis Ijazah Sarjana Muda Sains serta Pendidikan (Kimia). Skudai: Universiti Teknologi Malaysia.

Baumfield, V. M., \& Oberski, I. O. (1998). What do teachers think about Thinking Skills? Quality Assurance in Education, 6(1), 44-51. http://dx.doi.org/10.1108/09684889810200386

Black, S. (2005). Teaching students to think critically. The Education Digest, 70(6), 42-47.

Choy, S. C., \& Cheah, P. K. (2009). Teacher Perceptions of Critical Thinking Among Students and Its Influence on Higher Education. International Journal of Teaching and Learning in Higher Education, 20(2), 198-206.

Duron, R., Limbach, B., \& Waugh, W. (2006). Critical Thinking Framework for Any Discipline. International 
Journal of Teaching and Learning in Higher Education, 17(2), 160-166.

Ghafar, M. N., Rahim, H, A., Sihes, A. J., \& Harun, A. (2010). Integrated Curriculum Concepts in Malaysia: Knowledge and Application Differentiation. European Journal of Social Sciences, 19(2), 208.

Halpern, D. F. (1999). Teaching for critical thinking: Helping college students develop the skills and dispositions of a critical thinker. New Directions for Teaching and Learning, 80, 69-74. http://dx.doi.org/10.1002/t1.8005

Hamzah, M. O., \& Sinnasamy, P. (2009). Between the ideal and reality: Teachers' perception of the implementation of school-based oral English assessment. The English Teacher, 38, 13-29.

Hashim, R. (2004). Investigation on the Teaching of Critical and Creative Thinking in Malaysia. Jurnal Pendidikan Islam, 10(1).

Hashim, R., \& Hussein, S. (2003). The Teaching of Thinking in Malaysia. Kuala Lumpur: IIUM Publication.

Ismail, A., \& Kanesan, A. G. (2011). Human Capital Development Practices in Malaysian Public Universities. Current Research Journal of Social Sciences, 3(5), 389-398.

Jones, M., \& Haynes, B. T. (1999). Teaching thinking skills: Mapping the arguments for curriculum choices revisited. Paper presented at the Australian Association for Research in Education Conference, Adelaide. Retrieved from http://www.google.com

Kaji Sistem Peperiksaan. (2004, September 9). Utusan Malaysia.

Mahyudin, R., Pihie, Z. A. L., Elias, H., \& Konting, M. M. (2004). The Incorporation of Thinking Skills in the School Curriculum, XXII(2).

Ng, L. Y., Kamariah, A. B., Roslan, S., Wong, S. L., Rahman, M. A., \& Zabariah, P. (2009). Self-Regulated Learning In Malaysian Smart Schools: The Environmental And Personal Determinants. Working Paper, Universiti Sains Malaysia.

Noor, A. M. (2008). Teaching Thinking Skills-Redesigning Classroom Practices. Brunei: Universiti Brunei Darussalam.

Noor, S. M. (2000). Keberkesanan Sekolah: Satu Perspektif Sosiologi. Serdang: Universiti Putra Malaysia.

Ong, E. T. (2006). The Malaysian Smart Schools Project: An Innovation to Address Sustainability. Paper presented in the 10th UNESCO-APEID International Conference on Education "Learning Together for Tomorrow: Education for Sustainable Development", 6-8 December 2006, Bangkok, Thailand.

Sahandri, M., \& Abdullah, S. K. (2009). Generic Skills Needed to Produce Human Capital with "First Class Mentality". European Journal of Social Sciences, 10(1).

Shah, R. N. S. S. A. (2004). Kaji Sistem Peperiksaan. Utusan Malaysia.

Sternberg, R. J., \& Williams, W. M. (2002). Educational psychology. Boston: Allyn and Bacon.

Swartz, R. J., \& Perkins, D. N. (1989). Teaching Thinking: Issue and Approaches. Cheltenham, Australia: Hawker Brownlow Education.

\section{Copyrights}

Copyright for this article is retained by the author(s), with first publication rights granted to the journal.

This is an open-access article distributed under the terms and conditions of the Creative Commons Attribution license (http://creativecommons.org/licenses/by/3.0/). 